\title{
SOUTHERN PORTUGAL - AN ARCHITECTURAL HERITAGE WITH STRONG ISLAMIC INFLUENCE
}

\author{
FERNANDO BRANCO CORREIA \\ CIDEHUS - Universidade de Évora, Portugal.
}

\begin{abstract}
The western part of al-Andalus was a peripheral zone of the Islamic World, far from the area of the Guadalquivir River and the Mediterranean coast. But in this western area there are important architectural elements from the Islamic era. In addition to the reuse of defensive and civilian structures from Roman times, there were military building programmes on the coastlines, from the 9th century onwards, with the arrival of Norse raiders. Moreover, some chronicles refer, for the 10th and 11th centuries, to the construction of 'qasaba'(s) (military enclosures) in some cities and the total reconstruction of city walls.

Recent archaeological activity has made evident traces of small palaces, houses and city walls but there is also an architectural heritage visible relative to other buildings - such as mosques and even small 'ribat'(s) along the coastline. Some techniques, like that of 'rammed earth', are known to have been common in the Almohad period.

In general terms, one can identify several remnants of buildings - religious, civil and military - with different construction techniques and traditions, not only the reuse of older constructions but also the erection of new buildings. On the other hand, it is possible to find parallels to these buildings in such varied areas as other parts of the ancient al-Andalus, North Africa, Syria and even Samarra (Iraq).

This area of the Iberian Peninsula, described in chronicles as Gharb al-Andalus, is a hybrid region, where different traditions converged, taking advantage of the legacy of previous periods, mixing that legacy with contributions from North Africa, different areas of the Mediterranean and even the Middle East. This 'Islamic legacy' is currently perceived as a regional legacy and is well preserved. Keywords: bench entrance, fortifications, qasaba, rammed earth, Vikings.
\end{abstract}

\section{INTRODUCTION}

The western part of al-Andalus was a peripheral zone of the Islamic World, far from the area of the Guadalquivir River and the Mediterranean coast. Its peripheral position meant that this region experienced special developments in the context of the Islamization of al-Andalus. This territory - known as Lusitania in the Roman period - roughly coincides with the 'Gharb Al-Andalus' of medieval Arabic written sources. After the arrival of the troops of Tariq ibn Ziyad and the conquest of Toledo in 711, Mérida - the administrative capital of the former Lusitania - was conquered by Musa ibn Nusayr in 712 and its inhabitants concluded submission treaties with 'Abd al-Aziz ibn Musa in the period between 714 and 716 . This means that, in terms of construction - both civil and military -many of the buildings of earlier times remained in operation, although they may have acquired new functions or new occupants. In general, it can be stated that there were no major changes in this territory during the 8th century in architectural terms, despite the arrival in al-Andalus, and seizure of power, in 756, of the Umayyad 'Abd al-Rahman, who fled from the Abbasid revolution in the Middle East.

\section{EMIRS, REBELS AND VIKINGS}

The first major change to affect the buildings inherited from earlier times, taking into account the written sources and archaeological data, was the construction of a Hisn (also called qasaba in later documents) in Mérida. This military structure - still well preserved and currently under study - was ordered by another Umayyad Emir of Cordoba, 'Abd al-Rahman II, 
in the 9th century. It was intended to enable the emirs of Cordoba to control a city where the rebellions against them - by various communities - were a constant problem.

This construction can be described as an almost quadrangular enclosure - about 137 by $132 \mathrm{~m}$ - built with stone blocks in the inner and outer sides, but it also incorporates architectural remains and funerary monuments from the Roman and late Roman periods [1]. The walls are approximately $2.7 \mathrm{~m}$ thick and in height they can reach up to $10 \mathrm{~m}$. All the towers are quadrangular and protrude slightly from the wall, but some were built at a later stage. Those later towers are linked to the first towers by an arch and projected to the outside albarrana towers, whose exact dating is still uncertain. In the same period a cistern was built as well as a small mosque. In order to enable the control of the Roman bridge, a second square structure, a Propugnaculum or antecastellum [2], was also built.

The qasaba of Mérida has been studied by several authors in recent decades and the more recent work carried out by Consorcio Monumental of Mérida allows us to understand the process of construction in almost all the western area of al-Andalus [3]. The construction technique is identical to the classical 'opus quadratum'. Its regular plan is similar to several quadraburgium built in Syria and North Africa [4]. This is the first major Umayyad public work in the Gharb al-Andalus and, as such, is well marked by epigraphic inscriptions. This military construction, reusing Roman spolia and a regular shape, common in some areas of the Islamic World at that moment, served as an important point of reference for the western regions.

Mérida was the starting point of numerous uprisings in the 9th century. One of the rebellions was led by a coalition of a Berber leader - Mahmud ibn al-Jabbar - and a muladi from Christian origin - Sulayman ibn Martin [5]. We know that Mahmud was expelled from Mérida and - after passing through areas of the current Alentejo and Algarve regions (the remains of a castle in Alferce belong to this period) - entered the service of the king Alfonso II of Asturias in the area around the Douro River. Mahmud probably established himself around the place known as Mafamude (in front of Oporto) [6], where he built several fortifications for the Asturian monarch. This information highlights the building abilities of the rebels coming from Mérida, the old capital of Lusitania, where Eastern, Mediterranean and Western traditions were mixing. Recent studies point out some characteristics in the castle of Santa Maria da Feira that can be linked chronologically with this period [7].

From 844, the western coast of al-Andalus suffered seaborne raids for the first time. In that year Viking boats attacked Lisbon and, in the same year, they also attacked Seville. This was the first of several attacks to occur during the 9th and 10th centuries [8]. A second expedition raided the coast of the Gharb in $245 \mathrm{H} / 859$. This new Norse expedition, according to C. Picard [9], raises less comments from the chroniclers linked to the Umayyad court; this paucity of sources may be linked to the fact that the Umayyads reactions, after 844, were very effective; i.e. there was a strong military response to those attacks. That response had an official component, linking local and central powers, but there is also some evidence that part of the military response may have come from local 'civilian' militia that included many volunteers coming from other regions.

In fact, the Umayyads of Cordoba, despite their difficulties in controlling territories around the Guadiana valley, were able to control the coastal areas of the Gharb al-Andalus. We know, from written sources and from recent archaeological works, that from this moment onwards some fortifications on the Atlantic coast were built or strengthened [10]. 
It is also from this time that references to new cities, like Silves or Sintra [11], started to appear. On the other hand, it is possible that the Umayyads and regional authorities had begun to put in place control and surveillance systems of the coastline. This may have led to the emergence of sites hosting communities engaged, at the same time, in the surveillance of the coast and praying, building what some archaeological literature call ribat(s) [12]. Several years ago, an archaeological site of its kind near Arrifana [13], in Aljezur (Algarve), was identified, excavated and studied. It was pointed out that parallels existed with a similar construction, the 'Rábita of Dunas de Guardamar' in Alicante (Spain). The occupation of this latter place was dated from the 9th to 11th centuries while for Arrifana the ceramics and other artefacts point to an occupation around the first half of the 12th century. Very recently a small mosque, similar to those known in Arrifana, near Praia das Maças [14], north of Lisbon and Sintra (on the coastline), was also identified. This new site is in visual contact with the area of the castle of Sintra - where archaeological remains of the 9th century, probably the moment when it was built, have been discovered. The castle of Sintra and its surrounding areas (including this new small mosque in Praia das Maças) are of exceptional importance. The small ribat area is in visual contact with Sintra and from that place it would be possible to warn the madina of Lisbon by triangular visual contact with Almada, Almaraz [15] (from maharis?) and even Palmela [16], a castle with important archaeological remains from the Islamic period. There is still no final study or archaeological remains that would permit the precise dating of the occupation of the site of Praia das Maças in the Islamic period, but this site enlarges the hypothesis of communication by triangulation during this period. This method of communication could be applied to other places, near Lisbon, with positive results in some areas, like the one of Cabo da Roca [17] and Azóia (from the Arabic al-Zawiya).

A second major revolt took place in Mérida in the second half of the 9th century. This revolt had 'Abd al-Rahman ibn Marwan al-Jilliqi as its main leader, and from the moment he lost control over the city of Mérida, the ancient capital of Lusitania began to lose its significance. Badajoz, founded by that same rebel with the agreement of the emir of Cordoba - Muhammad I - became the new main city in the region. This Ibn Marwan built not only the first walls of Badajoz, but also baths and a mosque. We have evidence that the city of Elvas, on the other side of the Guadiana River, was also founded in this period [18]. Both Badajoz and Elvas have traces of similar small square towers from these first walls. Marvão and Idanha, further north, were also occupied by this andalusi rebel some time later, and there are interesting remains in those places as well [19].

However, there is an event that was particularly critical to the fortification process in western al-Andalus: the attack on the city of Évora, in 913, by Ordoño II, a future king of Asturias and Leon. According to chronicle al-Muqtabis of Ibn Hayyan, Évora was surrounded by the troops of Ordoño II, 30,000 men according to that text, albeit a clearly exaggerated number. Ordoño inspected the walls and noted that they were poorly constructed [20]. Those walls were Roman in origin, but they had been poorly preserved as they were too low and devoid of merlons and battlements. But most important of all was the fact that, outside the wall, there was a 'high hill of debris' produced by the townspeople, who had cast their rubbish and waste there from the inside of the city walls. The garbage, according to this Arabic source, almost reached the top of the city wall at some point. Ordoño attacked Évora and most of the inhabitants of the city were killed. The al-Muqtabis refers to the existence of 'old' buildings where members of some important families took refuge. The text says 'ten men known among them took refuge with their families in some 
old buildings' [21]; this is a reference almost secure to Roman buildings, one of which has a notable presence in the town even today.

The final destruction of Évora did not come at the hands of the emir (and future Caliph) of al-Andalus but was the work of the grandson of the rebel of Mérida, 'Abd Allah ibn Muhammad ibn 'Abd al-Rahman ibn Marwan ibn al-Jilliqi, lord of Badajoz. This regional leader destroyed the walls of Évora to avoid their use by Berber troops that were near. Later, however, the same rebel invited a muwallad friend (al-Surunbaqi) to occupy the deserted city and Évora would be rebuilt. But there's more; we know by the same source that there were a programme and a campaign to improve the quality of the defence structures in the Gharb al-Andalus at the beginning of the 10th century [22].

\section{CALIPHS IN THE WEST}

A few years later, this regional dynasty lost power and the first caliph of the Umayyads of al-Andalus, 'Abd al-Rahman al-Nasir, came to control all the western territory of alAndalus. This takeover began in 929 and heralded significant architectural changes. Similar to what happened in Mérida (during the 9th century), the existing written sources refer to the creation of qasaba in several cities, one of them being Beja [23]. These qasaba served to house garrisons loyal to the caliph of Cordoba, and not all are mentioned in written sources. It's possible to see traces of those qasaba in the cities of Lisbon, Santarém, Silves and others, usually at the highest point or in a militarily significant point of the city. The castle of Faro, adapted to a factory in the 20th century, may have to do with this qasaba creation process.

Throughout the 10th century the Viking raids on the Atlantic coast continued and, on the other hand, the Iberian West played an important role in Muslim military campaigns against Santiago de Compostela. Thus, the existence of several castles on the ancient coastline of the west, such as Alcobaça and Atouguia, could have its genesis or origin at this time, and others, like Sintra, Almada or Alverca, may have been built before and reused in this period [24]. The same can be said for the fortifications and sites in the Sado River area - such as Palmela, Alcacer and Setubal, near the mountains of Arrábida [25].

On the other hand, the fortification known as 'Cava de Viriato', in Viseu - an octagonal camp defined by embankments, with perimeter of about $2 \mathrm{~km}$ - which was for centuries considered a building dating from Lusitanian or Roman times, may well actually be from the Islamic period (Fig. 1). Its resemblance to a building in Samarra (Iraq) indicates that it may have to do with Almansor campaigns in the late 10th century [26]. The possible inspiration from models in distant Islamic territories is stimulating. Almansor, a military leader who always valued the prestige that came from eastern regions, may have left in the western area of al-Andalus other examples of solutions already tested in the eastern part of Dar al-Islam. Not very far from Viseu, in the top of Coimbra, a very regular fortification was recently discovered and excavated. It is also a qasaba, with a regular quadrangular plan, with semicircular towers [27]. This building has parallels with the Aljaferia of Zaragoza (Saragossa) and may be very important to our understanding of many other fortifications built with this kind of plan and this type of tower.

\section{TAIFAS IN GHARB AL-ANDALUS}

The qasaba may have also been very important throughout the 11th century, when the previous unity of al-Andalus fell apart and it was fragmented into several kingdoms (or Taifas). In the western area of al-Andalus there were also kingdoms with their capitals in several 


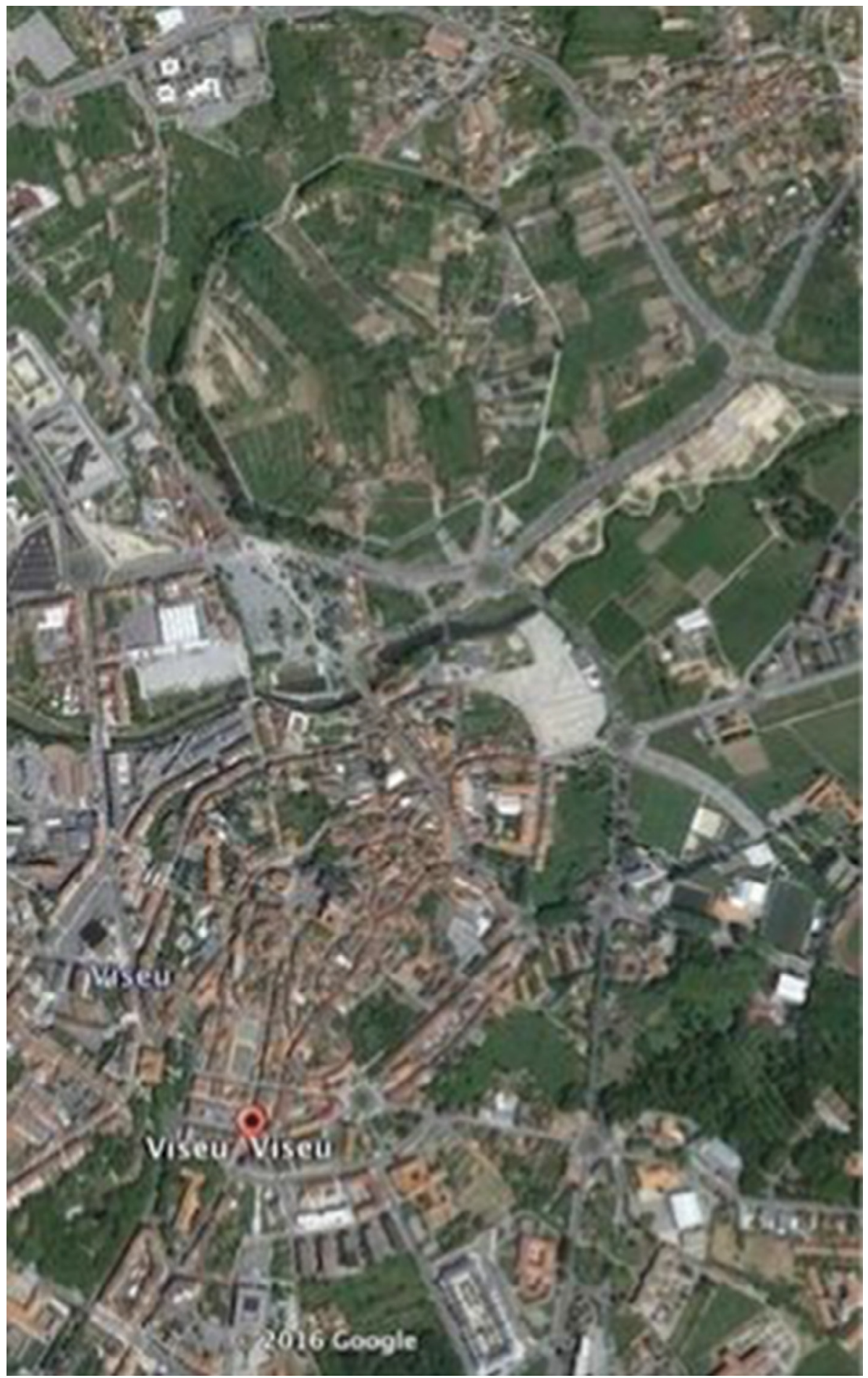

Figure 1: Cava Viriato in Viseu. 


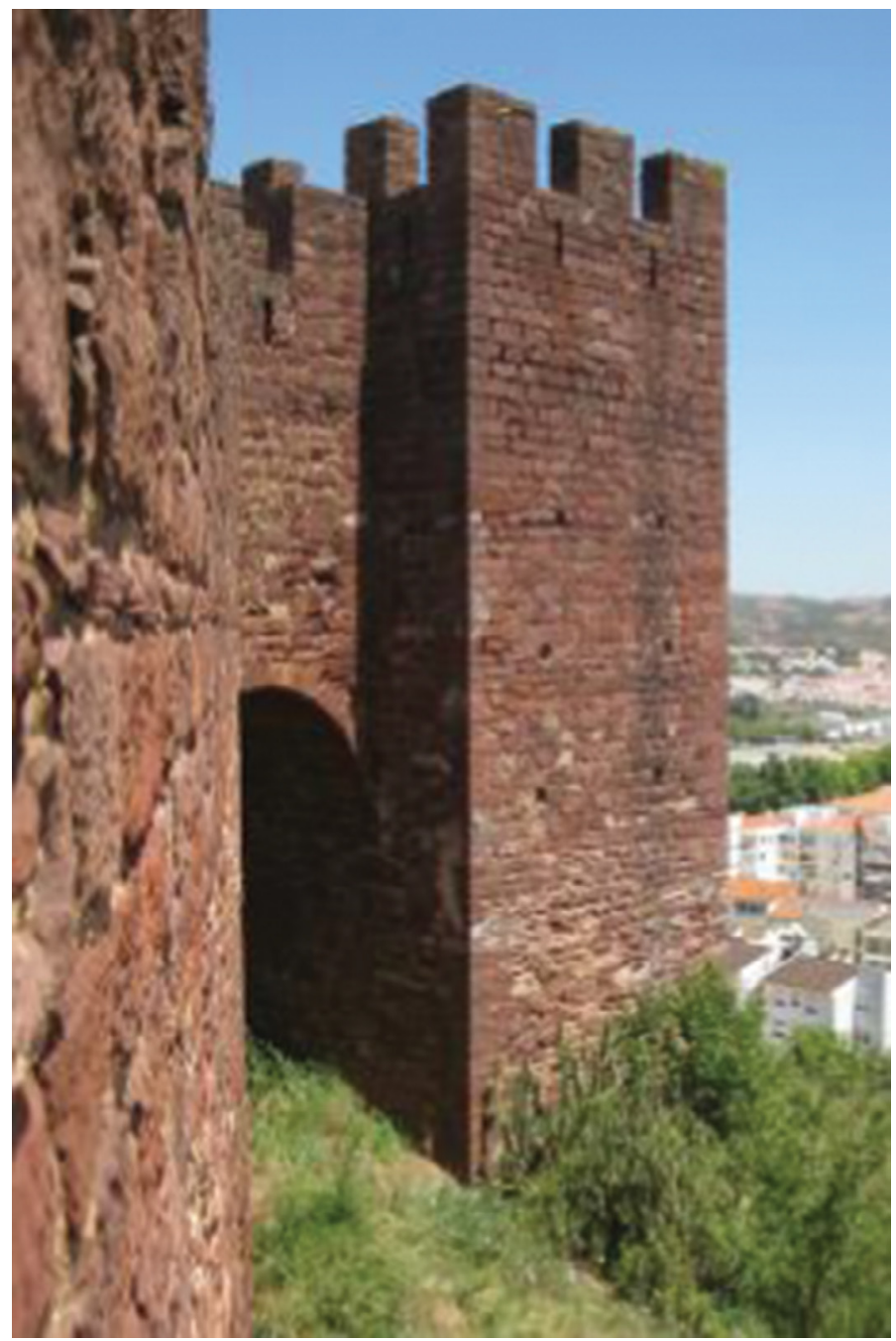

Figure 2: albarrana in the qasaba of Silves.

regional cities - Mértola, Silves and Faro - and there were two kingdoms, Badajoz and Seville, which held sway over important cities in the west, including Évora (under the control of Badajoz) and Beja (under the control of Seville). There is evidence that the qasaba of those cities became spaces of power (Fig. 2), with other facilities, such as palaces or baths, occupied by representatives of the ruling families, sometimes members of the founding dynasties of these kingdoms, but there is unfortunately a lack of information in architectural terms.

\section{THE ALMORAVIDS}

The conquest of Toledo by Alfonso VI in 1085 paved the way for a new era in al-Andalus. The more important dynasties of the Taifa kingdoms opened the way to the entry of the Almoravids into the Iberian Peninsula, which lead them to gradually take over al-Andalus. 
This dynasty invested militarily in the west of the peninsula, recovering Lisbon and Santarém, offered by the last Muslim king of Badajoz to Alfonso VI of Leon and Castile. A recent work about Santarem shows that there are vestiges of this period in the walls of this city, with an important 'bent entrance' [28]. In Lisbon the old wall from the final period of the Roman empire remained but it was strengthened with military improvements: a differentiated space, with walls, in the hilltop - a kind of acropolis or qasaba - where archaeological excavations have detected houses from that period; on the other hand, the entry systems became more complex and were bolstered by towers connected to the outer Roman origin wall, i.e. albarrã (or albarrana) towers. Aside from those innovations introduced in Almoravid period in previous fortifications, it is possible that some new constructions were made - probably by local artisans and masons; that may be the case of some parts of the fortifications of Leiria, Tomar, Torres Novas and, in the Alentejo region, a place called 'Castro da Cola' [29].

\section{THE ALMOHADS - ENDURING TRACES}

In the middle of the 12th century the Almoravid dynasty gave signs of weakening and a new dynasty from North of Africa took power in the Maghreb and al-Andalus - the Almohads. This was the last North African dynasty present in the western part of the territory of alAndalus. The Almohads focused their power around Seville and, in the second half of the 12th century, suffered some losses in this western part of the Iberian Peninsula. In response, they carried out a number of significant alterations, reinforcements and upgrades and even constructed new buildings from that point onwards. Such works of military nature were often associated with the building of new mosques or palatial or residential structures.

From a medieval written source it is possible to get an idea of the complexity of the defensive structure of Silves, in 1189, when this city was attacked by Sancho I of Portugal and by crusaders. The city had four fortified spaces, with an 'alvierana' (or albarrana) tower and what could be a special tower for observation - the 'Burge Marie' [30]. The loss of Silves in 1189 led this new dynasty to organize a military response, and the Almohad victory in the Alarcos battle, in 1195, encouraged it to strengthen the most important defensive structures in the western region. They employed specialized technicians who combined the constructive traditions of al-Andalus with knowledge and common techniques that came from the territory of origin of the Almohads - North Africa.

In $600 \mathrm{AH}$ (September 1203 - August 1204) the walls of Badajoz were repaired and the use of rammed earth, almost present in all the military testimonies from the Almohad period, became a strong characteristic of this period. Some time later, many other fortifications in what is now the Spanish Extremadura, Alentejo and the Algarve also received important modifications. In fact, the architectural legacy from that period is very strong in those areas. The military walls went through transformations, as well as extensions and the building of new fortifications. The construction and propagandistic programme of the Almohads stressed the defence and strengthening of the community, which is why the buildings from this period also include mosques and other kinds of edifices.

Strong walls of rammed earth, reinforced with calcium oxide (lime) from this period, are well known to have existed in Seville [31]. But in the south of Portugal they begin to appear in the last two decades of the 12th century. Some examples can be observed in Elvas, Alcacer do Sal, Noudar, Moura, Serpa, Silves (Fig. 3), Paderne, Loulé, Salir, Tavira, among others [32]. In some cases they are very well preserved and protected as local and historical heritage. Sometimes it is difficult to find those traces but work is presently being carried out to give value to what remains from the Almohad and andalusian past. In some cases, it is possible to 
detect polygonal towers, similar to those of 'Espantaperros' (in Badajoz), 'Torre Redonda' (in Cáceres) or 'Torre del Oro' in Seville. Tavira offers a good example of this kind of tower (Fig. 4) and in Alcacer there are traces of one. The Livro das Fortalezas, a 16th-century Portuguese book about fortifications, shows towers of this type (generally octagonal) in other fortifications [33].

Another characteristic of this period is the presence of towers that are separated from the main wall of a fortress but attached to it by an arch - the albarrã or albarrana towers. Paderne has a good example of this type of tower, but in Alcacer, Loulé and Salir there are other examples. In Silves it is possible to observe several examples of this type of tower - in the qasaba (Fig. 3) and in the madina walls. In Tavira, on the other hand, there is also a few dozen metres of the barbican, recently restored [33, p. 213].

Another important feature of the Almohad period is the presence of 'bent entrance' systems. In the west, these entrances are now well studied in Badajoz - such as the 'Puerta del Capitel' [34] - and in Cáceres. But, in the southern region of Portugal, there are also examples of these constructions, mainly from this period. There are mentions of the existence of 'complex entries' in Lisbon, in 1147, but the more important examples of this kind of entrance are from Almohad period. The recently studied the 'Porta do Temple' (or 'Temple Gate') in the qasaba of Elvas is a good example of this system, but there are other important remains in Paderne (near Albufeira) and in Mértola - not only in the 'Porta do Rio',

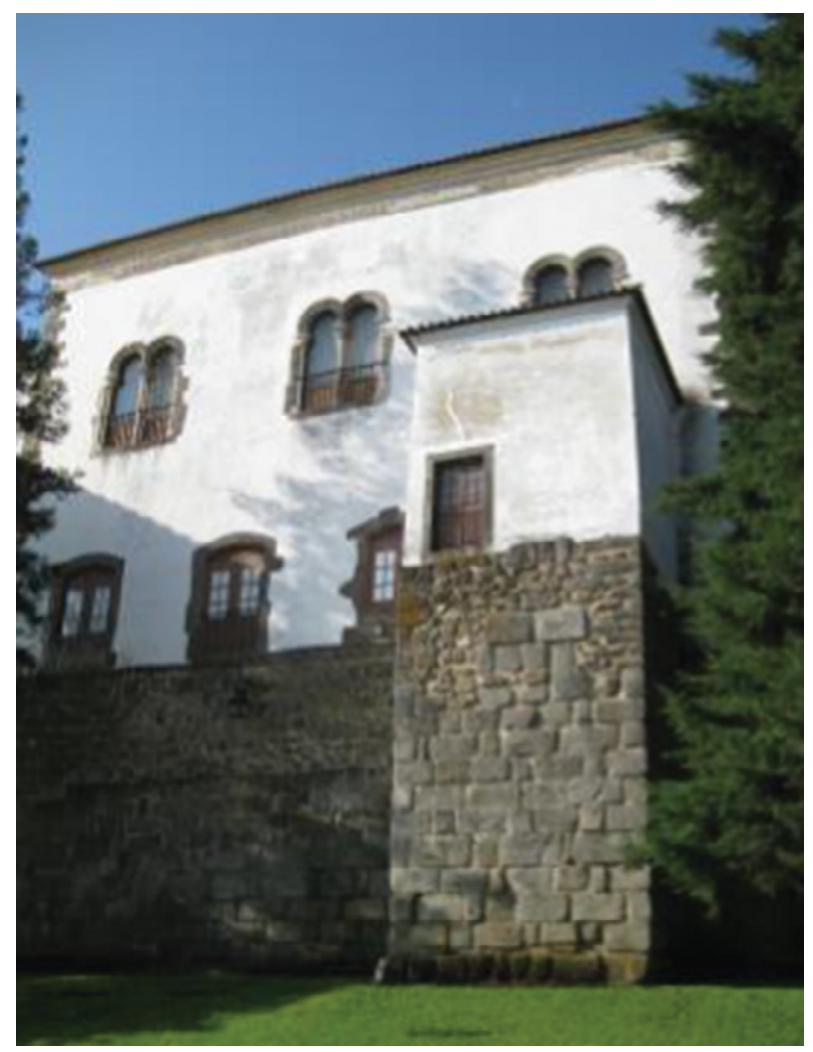

Figure 3: Évora walls in the qasr area 


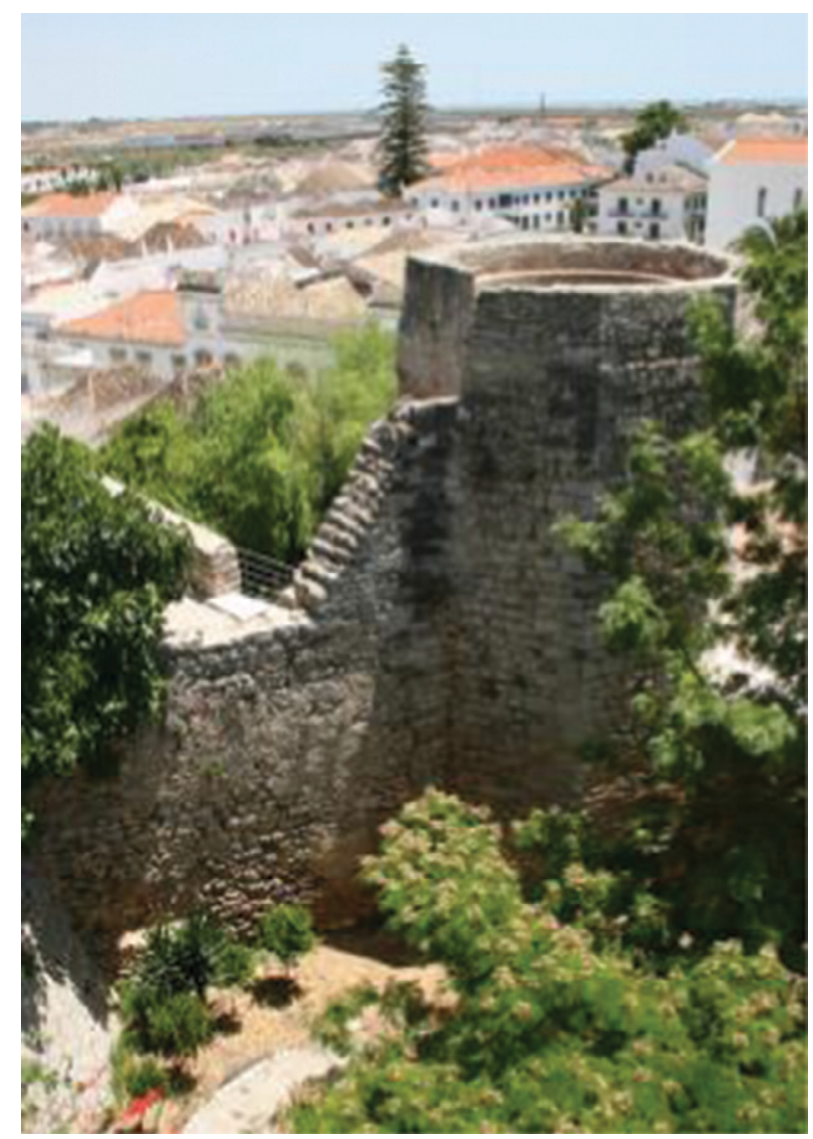

Figure 4: Tavira Almohad tower.

an entrance to the madina near the Guadina River, but also in the main entrance of the castle, featuring a double- bent entrance [35]. Through the iconography of the 17th century it is possible to identify bent entrances in Santa Mariyya al-Gharb (Faro - Fig. 5) - one of them partially conserved - and in Albufeira. Special attention deserves to be paid to the entrance called 'Portas de Loulé, in Silves; in Faro, the 'Porta da Vila' and the complex entry called 'Arco do Repouso', modified in the beginning of the 20th century but still preserved, are good examples of these entrances. The town of Lagos has an entrance called 'Porta de Sao Gonçalo' that could be from that period or from the beginning of the Portuguese administration of the town [36].

The construction and propaganda programme of the Almohads did not only leave military traces. In Mértola there are important elements of the ancient Almohad mosque - the mihrab, the qibla and some of the original doors (Fig. 6) [37]. The study of the andalusi period in Elvas shows the possible existence of remains of an Almohad mosque in the qasaba; the wall of the qibla has, almost in the middle, the shape of what could be the mihrab; ancient documentation shows the minaret that collapsed in the 18th century [38]. In addition, there are also indications of the existence of ancient mosques - probably from the Almohad period - in Alcacer do Sal, Loulé and Tavira [39]. 


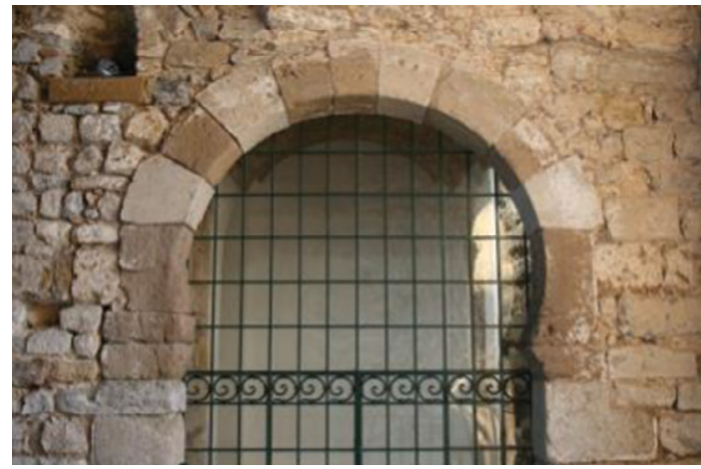

Figure 5: Faro (arch in the madina from Islamic period).

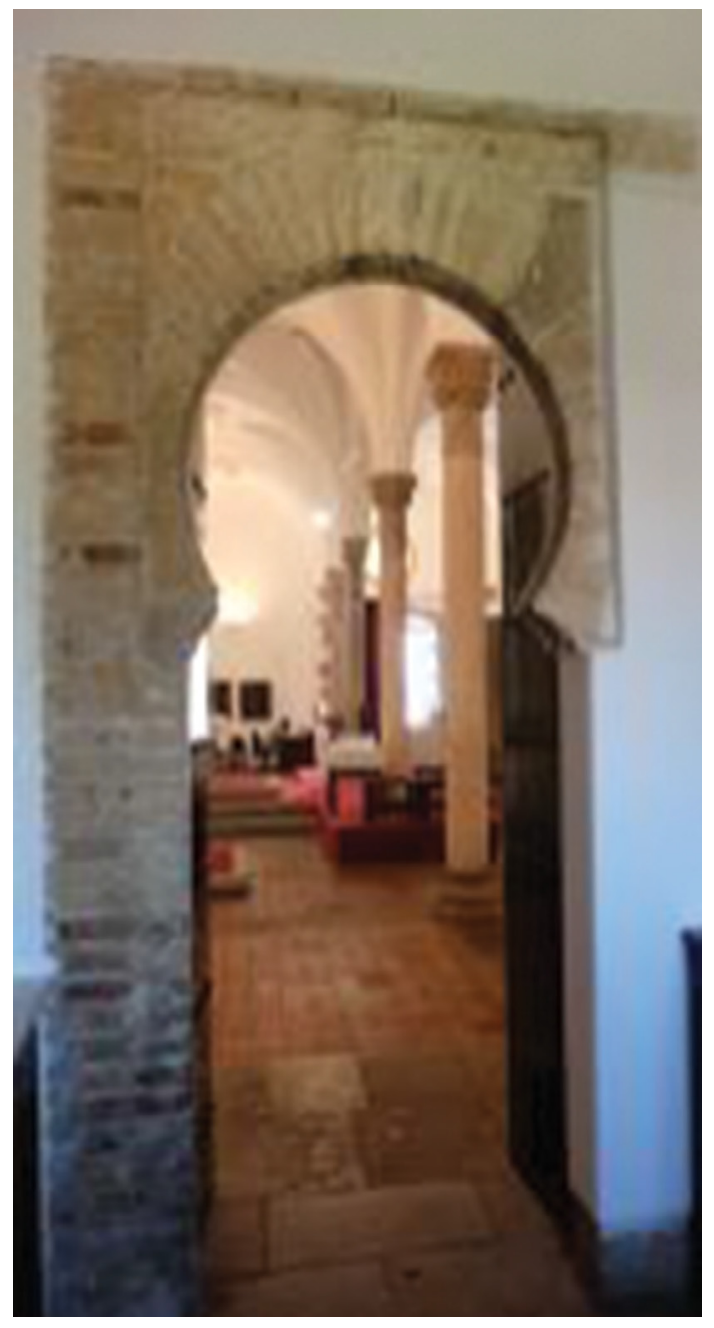

Figure 6: Mertola (arch and interior of the mosque). 
The legacy of those centuries also includes hydraulic structures. The most important of all is the 'cistern' discovered a few decades ago in Silves, a rare example of a hydraulic structure with staircase arranged around a central pit column. This structure has similarities to an existing structure in Aleppo - the satura [40]; it is not impossible to say that contact and exchanges of military knowledge took place between the Almohad and Ayyubid dynasties.

When we speak about the architectural legacy from this period in the south of Portugal it is impossible to ignore the Almohad borough in Mértola, with several houses arranged around a central courtyard and streets, from which it was possible to know much of the everyday richness of this city in the 12th and 13th centuries. This legacy is well preserved, having given rise to important scientific and divulgation publications. The study of this site in Mértola has allowed the creation of an important museum and a renowned centre of international research - the Campo Arqueológico de Mértola.

\section{AN ENDURING LEGACY}

The disappearance of the dynasties of Islamic origin in the western part of al-Andalus did not put an end, in Portugal and Spain, to the influence of several centuries of traditions and innovations coming from Islamized territories. The southern Portuguese regions came to use many techniques and forms that are continuations of these traditions. In addition to a socalled Mudejar architecture that flourished around cities such as Évora there are cases where the techniques are associated with words, as in the castle of Alandroal. This fortification was built for the Military Order of Avis by a Muslim architect; beyond the presence of a horseshoe-shaped arch with alfiz and the use of built techniques from andalusi tradition, we can find there a gravestone with an inscription in Latin characters which, incredibly, reproduce the motto of the Nasrid dynasty of Granada [41].

To conclude, it can be said that the architectural legacy of those centuries is still poorly known and, in some cases, needs further study. However, it can also be argued that several centuries of Islamic presence in the western territory of the Iberian Peninsula reflect not only continuities, changes and developments, but also technological and cultural hybridity. Many of the structures from the classical era continued to stand, gaining new functions, sometimes being expanded, rebuilt and improved; some of those structures witnessed the arrival of technology and inspiration from North Africa or the Middle East. The centuries of the andalusi presence in this region are centuries of evolution, change and innovation, testing new forms and techniques, bringing into contact the knowledge of different regions.

Many forms and techniques persisted in the south of Portugal for a long time after the end of the Arab and Islamic presence, giving rise, sometimes, to situations of cultural and technical hybridity. By the study of these remains, this presence will not be forgotten.

This architectural legacy is valued and cherished. It is seen not only as a local legacy but also as a bridge with the past as well as the future. It is a legacy whose study is intended to be positive for everyone. It is, after all, a part of the World Heritage, wishing to connect all of humanity.

\section{REFERENCES}

[1] Hernández Giménez, F., The Alcazaba of Mérida, Early Muslim Architecture, Part Two, ed. K.A.C. Creswell, Oxford at the Clarendon Press, pp. 197-205, 1940.

[2] Valdés, F., El propugnaculum de Mérida y la tradición arquitectónica bizantina en al-Andalus, Revista de Estudios Extremeños, 52, pp. 463-485, 1996.

[3] Alba, M. \& Feijoo, S., Defensas urbanas de la Mérida islámica, Al-Andalus Espaço de Mudança. Balanço de 25 anos de História e Arqueología Medievais. Homenagem 
a Juan Zozaya, Mértola, CAM, pp. 101-110, 2005; Feijoo, S. \& Alba, M., 'El sentido de la Alcazaba de Mérida: su aljibe, mezquita y torre de señales'. Memoria 8 , Mérida, pp. 576-579 \& 583, 2005.

[4] Genequand, D., Umayyad castles: the shift from late antique military architecture to early Islamic palatial building, Muslim Military Architecture in Greater Syria. From the Coming of Islam to the Ottoman Period, eds. Hugh Kennedy, Brill: Leiden, pp. 3-25, 2006.

[5] Ibn Hayyan, Crónica de los emires Alhakam I y Abdarrahman II entre los años 796 y 847 [Al-Muqtabis II-1], I.E.I.O.P., Zaragoza, 2001, p. 181v.

[6] Livermore, H. V., O Baixo Douro no século IX. A colónia de Mahmud Ibn cAbd al-Djabbar, Actas - Congresso Histórico de Guimarães e sua colegiada, V, Guimarães, pp. 145-152, 1982; CORREIA, F. B., Fortificação, guerra e poderes no Garb al-Andalus, Universidade de Évora, p. 148-182, 2011 (https://dspace.uevora.pt/rdpc/ handle/10174/11908).

[7] Barroca , M. J., Fortificações e Povoamento no Norte de Portugal (Séc. IX a XI), Portugália, XXV, p. 188, 2004.

[8] Dozy, R., Los Vikingos en España, Madrid, ed. Polifemo, pp. 13-17, 1987; Christys, A., Vikings in the South: Voyages to Iberia and the Mediterranean, Bloomsbury Academic, London, ISBN 978-1-4742-1-375-2, pp. 41-45, 2015.

[9] Picard, Ch., L'Océan Atlantique Musulman. De la conquête arabe à l'époque almohade, Maisonneuve et Larose/Unesco: Paris, p. 75, 1997.

[10] Correia, F.B., Fortificações de iniciativa omíada no Gharb al-Andalus nos séculos IX e $\mathrm{X}$ - hipóteses em torno da chegada dos Majus (entre Tejo e Mondego), Fortificações e território na Península Ibérica e no Magreb (séculos VI a XVI), ed. Fernandes, I.C.F., Lisboa, vol. 1, pp. 77-78, 2013.

[11] Picard, Ch., Le Portugal Musulman (VIIIe - XIIIe siècle). L'Occcident d'al-Andalus sous domination islamique, Maisonneuve \& Larose: Paris, pp. 199-200, 2000; Coelho, Catarina, A ocupação islâmica do Castelo dos Mouros (Sintra): interpretação comparada, Revista Portuguesa de Arqueologia, vol. 3.1, Lisboa, IPA, pp. 207-225, 2000.

[12] Azuar Ruiz, R., El ribât en al-Andalus : espacio y función', Espacios religiosos islámicos (éd. J.A. Soutos), 'Ilu - Revista de Ciencias de las religiones. Anejos, 10, pp. 23-38, 2004.

[13] Gomes, R.V. \& Gomes M.V., Ambiente natual e complexo edificado, Ribat da Arrifana: cultura material e espiritualidade, Aljezur, pp. 51-64, 2007; Gomes, R.V. \& Gomes M.V., O ribat da Arrifana (Aljezur, Algarve): resultados da campanha de escavações arqueológicas de 2003 - sector 1, Revista Portuguesa de Arqueologia, Vol. 8, N. 2, Lisboa, I.P.A., pp. 471-533, 2005.

[14] http://museuarqueologicodeodrinhas.cm-sintra.pt/escavacoes/1/alto-da-vigia.html (accessed 02 October 2013).

[15] Correia, F.B., A acção do poder político nas actividades portuárias e na navegação no ocidente islâmico. Alguns tópicos, Economia e instituições na Idade Média. Novas abordagens, eds. Solórzano, J.A. \& Viana, M., Ponta Delgada, C.E.G.F., p. 35, fig.1, 2013.

[16] Fernandes, I.C.F., O Castelo de Palmela: herança islâmica e domínio da Ordem de Santiago, Mil anos de Fortificações na Península Ibérica e no Magreb (500-1500), C. M. Palmela - Colibri Ed., pp. 571-578, 2001.

[17] Borges, M.O., A defesa costeira do litoral de Sintra-Cascais durante o Garb al-Ândalus. I, História. Revista da FLUP, Porto, 2, pp. 109-128, 2012. 
[18] Correia, F.B., O sistema defensivo da Elvas islâmica, Mil Anos de Fortificações na Península Ibérica e no Magreb (500-1500), ed. Fernandes, I.C.F., Lisboa, Ed. Colibri/ C.M.P., pp., 357-367, 2001.

[19] Zozaya, J., Las fortificaciones andalusíes, Artigrama, 22, p. 243, 2007; Torres, C. \& Macias, S., O Legado Islâmico em Portugal, Lisboa, Fund. Círculo de Leitores, pp. 76-79, 1998.

[20] Ibn Hayyān, Crónica del Califa 'Abdarrahman III an-Nasir entre los años 912 y 942 (al-Muqtabis V), Zaragoza, 1981, fl.63; transl. p. 82; Sidarus, A., Um texto Arabe do século $\mathrm{X}$ relativo à nova fundação de Evora e aos movimentos muladi e berbere no Ocidente Andaluz, A Cidade de Evora, n. 71-76, (XLV-L), Evora, pp. 7-37, 1994.

[21] Ibn Hayyān, al-Muqtabis V, p. 81 (ed. Sidarus, §15, p. 16).

[22] Ibn Hayyān, al-Muqtabis V, p. 83 (ed. Sidarus, §23, p. 17).

[23] Correia, F. B., Da Lusitânia ao domínio omíada. Beja como tela de fundo de uma reflexão, O Sudoeste Peninsular Entre Roma e o Islão - Southwestern Iberian Peninsula between Rome and Islam, CAM, Mértola, pp. 185-187, 2014.

[24] Correia, F. B., Fortificações de iniciativa omíada no Gharb al-Andalus nos séculos IX e X, Fortificações e território na Península Ibérica e no Magreb (séculos VI a XVI), ed. Fernandes, I.C.F., Lisboa, vol. 1, pp. 78-80, 2013.

[25] Picard, Ch., Fernandes I.C.F., La défense côtière au Portugal à l'époque musulmane: l'exemple de la presqu'île de Setúbal , Archéologie Islamique, 8-9, p. 67-94, 1999; Fernandes, I.C.F., A península de Setúbal em Época Islámica, Arqueologia Medieval, 7, Porto - C.A.M., p. 185-196, 2001.

[26] Northedge, A., The Historical Topography of Samarra, British School of Archaeology in Iraq, p. 176 (fig.71), p. 175 (fig.74), PL. 23, 2005; Mantas, V., Indícios de um Campo Militar Romano na 'Cava De Viriato'?, Al-Madan. $2^{a}$ série, 12, Almada, pp. 40-42, 2004; Mascarenhas, J. M. \& Barata, F.T. (Eds.), Cava de Viriato-História, Paisagem e Património, Viseu, ViseuPolis, pp. 47-50, 2008.

[27] Alarcão, J., Coimbra: a montagem do cenário urbano, Coimbra, I. U.C., pp. 73 (fig. 38), pp. 111 \& 129, 2008.

[28] Correia, F.B., Fortificações pós-califais do sudoeste peninsular. Investigações e hipóteses sobre um tema, Bataliús III, Estudios Sobre El Reino Aftasí, Zozaya \& Kurtz Schaefer eds., Badajoz, pp. 197-203, 2014.

[29] Discover Islamic Art, Museum with no Frontiers, http://www.discoverislamicart.org/ database_item.php?id=monument;ISL;pt;Mon01;30;pt (accessed 12 April 2015).

[30] David, C. W., Narratio de itinere navali peregrinorum Hierosolymam tendentium et Silviam capientum A.D. 1189, Proceedings of the American philosophical society, 81-5, p. 620, n. 156, 1939; Correia, F.B., Fortifications et stratégies pour la frontière du Gharb al-Andalus en époque almohade, pp. 51-53, 2015.

[31] Valor Piechotta, M. \& Ramírez del Río, J., Sobre la cronología de las murallas, Sevilla Almohade, Sevilla - Rabat, pp. 27-53, 1999.

[32] Correia, F.B., Fortificações urbanas de época islámica no Algarve, Património Islâmico dos Centros Urbanos de Algarve: Contributos para o Futuro, Faro, C.C.R.A., pp. 81-90, 2002.

[33] Correia, F.B., Fortificações pós-califais do sudoeste peninsular. Investigações e hipóteses sobre um tema, Bataliús III, Estudios Sobre El Reino Aftasí, eds. Zozaya, J., \& Kurtz Schaefer, G. (eds.), Badajoz, pp. 215-216, 209 (fig.14), 2014. 
[34] Correia, F.B., Elvas na Idade Média, Cidehus/UE/Colibri, pp. 101-122, 2013; Márquez Bueno, S. \& Gurriarán Daza, P., Recursos formales y constructivos en la arquitectura militar almohade de al-Andalus, Arqueología de la Arquitectura, 5, Madrid, CSIC, p. 134, fig. 27, 2008.

[35] Boiça, J. \& Barros, F.R., O Castelo de Mértola - História, Espaço e Formas, sécs. XIII-XXI, Mértola, C.M.M., 2013, pp. 31, 40, 91, 94-95; Correia, F.B., Fortificações pós-califais do sudoeste peninsular. Investigações e hipóteses sobre um tema, Bataliús III, p. 191 (fig.6), 2014.

[36] Correia, F.B., Fortifications et stratégies pour la frontière du Gharb al-Andalus en époque almohade Entre Islam et Chrétienté La territorialisation des frontières, xie-xvie siècles, eds. Boissellier, S. \& Fernandes, I., P. U. Rennes, pp. 57-60, 2015.

[37] Macias, S. \& Torres, C., A mesquita de Mértola, Mesquita Igreja de Mértola, Mértola, C.A.M., pp. 9-30, 2011.

[38] Correia, F.B., Elvas na Idade Média, pp. 75-87, Cidehus/UE/Colibri, 2013.

[39] Torres, C. \& Macias, S., O Legado Islâmico em Portugal, Lisboa, Fund: Círculo de Leitores, pp. 212-215, 1998.

[40] Gomes, R.V., O poço-cisterna almóada de Silves (Algarve, Portugal), I Coloquio de Historia y Medio Físico - El água en zonas aridas, vol. II, Almería, pp. 577-606, 1989; Bianca, S., (ed.), Syria. Medieval Citadels between East and West, Italy: Aga Khan Trust for Culture, p. 120 (fig. 97), p. 124, 2007.

[41] Correia, F.B., Fortificações pós-califais do sudoeste peninsular. Investigações e hipóteses sobre um tema, Bataliús III, pp. 215-16, 2014. 